\title{
Effectiveness of composite resin polymerization using light- emitting diodes (LEDs) or halogen-based light-curing units
}

\author{
Efetividade de polimerização de uma resina composta \\ fotopolimerizada por diodos emissores de luz (LEDs) ou \\ luz halógena
}

\author{
Bianca Micali* \\ Roberta Tarkany Basting**
}

\begin{abstract}
The clinical performance of composite resins is greatly influenced by the quality of the light-curing unit used. The aim of this study was to compare the efficiency of a commercial light-emitting diode (LED) with that of a halogen-based light-curing unit by means of dye penetration of a micro hybrid composite resin. The composite resin evaluated was Filtek Z250 (3M Dental). The composite was filled into acrylic moulds that were randomly polymerized for 40 seconds by each of the light-emitting systems: light-emitting diode Ultraled (Dabi Atlante) or halogen light Degulux (Degussa Hüls) curing units. Immediately after polymerization, each specimen was individually immersed in $1 \mathrm{ml}$ of $2 \%$ methylene blue solution at $37^{\circ} \mathrm{C} \pm 2^{\circ} \mathrm{C}$. After 24 hours, the specimens were rinsed under running distilled water for 1 minute and stored at $37^{\circ} \mathrm{C} \pm 2{ }^{\circ} \mathrm{C}$ at relative humidity for 24 hours. The composite resins were removed from the moulds and individually triturated before being immersed in new test tubes containing $1 \mathrm{ml}$ of absolute alcohol for 24 hours. The solutions were filtered and centrifuged for 3 minutes at 4,000 rpm and the supernatant was used to determine absorbance in a spectrophotometer at $590 \mathrm{~nm}$. To verify the differences between groups polymerized by LED or halogen light $t$-test was applied. No significant differences were found between composite resins light-cured by LED or halogen light-curing unit $(p>0.05)$. The commercially LED-based light-curing unit is as effective to polymerize hybrid composite resins as the halogen-based unit.
\end{abstract}

DESCRIPTORS: Composite resins; Spectrophotometry.

RESUMO: A longevidade clínica das resinas compostas é grandemente influenciada pela qualidade do aparelho fotopolimerizador utilizado. O objetivo deste trabalho foi comparar a eficácia de um aparelho fotopolimerizador de diodos emissores de luz e a de um de luz halógena através do grau de penetração de um corante em uma resina composta micro-híbrida. A resina composta utilizada (Filtek Z250/3M Dental) foi inserida em matrizes acrílicas e fotopolimerizada por 40 segundos por um aparelho fotopolimerizador de diodos emissores de luz (Ultraled/Dabi Atlante) ou de luz halógena (Degulux/Degussa Hüls). Imediatamente depois, os corpos-de-prova foram imersos em $1 \mathrm{ml}$ de solução de azul de metileno a $2 \%$ e mantidos em estufa a $37^{\circ} \mathrm{C} \pm 2^{\circ} \mathrm{C}$. Após 24 horas, foram lavados com água corrente destilada por 1 minuto e armazenados em estufa a $37^{\circ} \mathrm{C} \pm 2^{\circ} \mathrm{C}$ em umidade relativa por 24 horas. As resinas compostas foram removidas das matrizes, individualmente trituradas e imersas em $1 \mathrm{ml}$ de álcool absoluto por 24 horas. As soluções foram filtradas e centrifugadas por 3 minutos a $4.000 \mathrm{rpm}$, e o sobrenadante foi utilizado para determinar a absorbância em um espectrofotômetro a $590 \mathrm{~nm}$. O teste $t$ foi aplicado para verificar as diferenças entre os grupos. Não houve diferenças estatísticas entre os grupos fotopolimerizados por diodos emissores de luz ou luz halógena ( $\mathrm{p}>0,05)$. O aparelho fotopolimerizador de diodos emissores de luz apresentou a mesma efetividade em polimerizar uma resina composta micro-híbrida quanto o de luz halógena.

DESCRITORES: Resinas compostas; Espectrofotometria.

\section{INTRODUCTION}

Dental composites are important materials employed in restorative procedures. However, composite resins still present some limitations, such as polymerization shrinkage, the necessity for procedures to avoid contact with humidity, low abrasion strength and color instability ${ }^{23}$.
In addition to technological improvements in composite resins, light-curing units have also attained better properties for complete restoration polymerization ${ }^{20}$. Halogen or quartz tungsten halogen lamps have been more widely employed than any other device as a practical alternative

\footnotetext{
* Undergraduate Student, School of Dentistry of Araras, Herminio Ometto University Center.

** Professor, Department of Restorative Dentistry, São Leopoldo Mandic Dentistry Research Center.
} 
Micali B, Basting RT. Effectiveness of composite resin polymerization using light-emitting diodes (LEDs) or halogen-based lightcuring units. Braz Oral Res 2004;18(3):266-70.

method for polymerizing resins, bonding systems, bases and liners, luting agents, and some provisional restorative materials. These units operate with a white halogen bulb, filtered to remove the undesirable wavelengths. However, a considerable number of other wavelengths are still emitted and absorbed by composite resins, inducing heating of material and tooth during the polymerization process. The decline of irradiance due to bulb's and filter's ageing over time by generated heat has also been reported ${ }^{12,15}$. The camphorquinone employed as a photoinitiator is sensitive to light of the blue region of the visible spectrum and the most adequate wavelength is within the $450-490 \mathrm{~nm}$ wavelength range ${ }^{16}$. Thus, any source of light with a reasonable irradiance within this range can be employed as a curing device. However, to obtain the correct irradiance of blue light to polymerize resins, a reasonable interval of time of around 40 seconds and a powerful light intensity emitted by the halogen lamp will be necessary (depending on the brand of the material), both related to the light density that reaches the resin.

A varied range of light unit systems have been introduced in the marketplace, like plasma arc lights (which are high intensity light units), argon ion laser, pulse delay, and ramped or stepped (softstart polymerization) output systems ${ }^{20}$ to decrease the time spent with polymerization procedures or to avoid gap formation, polymerization shrinkage and pulp damage ${ }^{22,23,25,27,28}$. However, light-emitting diodes (LED), specifically LEDs with gallium nitride blue as a semiconductor, demonstrated advantages in preventing overheating due to spectral purity, achieving highly efficient dental composite polymerization. The energy range between $450-490 \mathrm{~nm}$ is ideal for activating materials that use camphorquinone as initiator and less power is required to operate these devices, eliminating the need for filters and a cooling fan, since heatproducing infrared wavelengths are eliminated. LEDs do not degrade over time and the light they produce has constant intensity ${ }^{11,20}$.

Some studies have reported that LED curing units show efficiency in hybrid composite resin polymerization ${ }^{1,8,13,14,21,24}$, induce less polymerization shrinkage ${ }^{6}$ and do not cause thermal changes in pulp tissues ${ }^{6,26}$. Leonard et al. ${ }^{11}$ (2002) showed that LED-based curing-lights require considerably longer exposure durations than the quartz tungsten halogen curing-light to adequately polymerize hybrid and microfill composite resins. Some studies used experimental LED units rather than commercial products and halogen light intensity, which the LED unit was compared with, was reduced to coincide with the reduced power density output of the LED unit ${ }^{8,13,21,24}$. Thus, composite resins polymerized by ineffective equipment may present low mechanical strengths and stains on the outer surface of the material, or even in the bulk of the material, which harms the physical properties of the restoration.

This study aimed to compare the efficiency of a commercial LED to a halogen-based curing-light unit by means of dye penetration of a micro hybrid composite resin.

\section{MATERIALS AND METHODS Experimental design}

Two light-curing units were under study: lightemitting diode (LED) Ultraled (Dabi Atlante, Ribeirão Preto, SP, Brazil) and halogen light Degulux (Degussa Hüls, Postfach, Hanau, Germany). The experimental units consisted of 40 composite resin specimens, randomly and evenly assigned to be polymerized by both light-curing devices $(n=20)$. Dye penetration variable response was evaluated by quantitative methods obtained by spectrophotometer tests.

\section{Specification of the materials}

A micro hybrid composite resin was evaluated: Filtek Z250 (3M Dental Products, St. Paul, MN, USA). Filtek Z250 is a composite resin that contains zircon glass and colloidal silica as inorganic fillers (batch number $1 \mathrm{LU}$, shade A2). The light-curing unit specifications are presented in Table 1.

\section{Specimen preparation and spectrophotometer tests}

Shade A2 of the micro hybrid composite was used in this study. The composite was filled into acrylic moulds, $4 \mathrm{~mm}$ in internal diameter and $2 \mathrm{~mm}$ in depth. A transparent Mylar strip (3M, SP, Brazil), a glass microscope slide and a load of 500 grams were placed on the top of the mould for a period of 30 seconds to extravasate excess material, avoid porosities and allow parallel planar surfaces. The slide and load were removed and the mould was randomly polymerized for 40 seconds with either the LED or the halogen light-curing units placed against the Mylar strip. The intensity of the light-curing units was monitored by a radiometer 
Micali B, Basting RT. Effectiveness of composite resin polymerization using light-emitting diodes (LEDs) or halogen-based lightcuring units. Braz Oral Res 2004;18(3):266-70.

TABLE 1 - Light-curing units' specifications and manufacturers.

\begin{tabular}{l|l|l|l}
\hline \hline \multicolumn{1}{c|}{ Type of light } & Light-curing unit & $\begin{array}{c}\text { Mean } \\
\text { intensity }\end{array}$ & \multicolumn{1}{c}{ Manufacturer } \\
\hline Quartz tungsten halogen light & Degulux & $570 \mathrm{~mW} / \mathrm{cm}^{2}$ & Degussa Hüls, Postfach, Hanau, Germany \\
\hline Light-emitting diodes & Ultraled & $110 \mathrm{~mW} / \mathrm{cm}^{2}$ & Dabi Atlante, Ribeirão Preto, SP, Brazil \\
\hline \hline
\end{tabular}

TABLE 2 - Mean values of composite resin dye concentration (in micrograms per milliliter) cured by each light-curing unit and $t$-test results $(\mathrm{p}>0.05)$.

\begin{tabular}{l|c|c|c}
\hline $\begin{array}{c}\text { Light-curing } \\
\text { unit }\end{array}$ & Mean & $\begin{array}{c}\text { Standard } \\
\text { deviation }\end{array}$ & t-test* \\
\hline Degulux & 0.1798 & 0.053 & $\mathrm{~A}$ \\
\hline Ultraled & 0.2122 & 0.072 & $\mathrm{~A}$ \\
\hline \hline
\end{tabular}

*Equal letters in column indicate mean values that are not significantly different.

(DMC, model CL150, São Carlos, SP, Brazil), after the preparation of every 5 specimens. The mean intensity of the units was $110 \mathrm{~mW} / \mathrm{cm}^{2}$ for the LED (ranging from $120 \mathrm{~mW} / \mathrm{cm}^{2}$ to $105 \mathrm{~mW} / \mathrm{cm}^{2}$ ) and $570 \mathrm{~mW} / \mathrm{cm}^{2}$ for the halogen lamp (ranging from $595 \mathrm{~mW} / \mathrm{cm}^{2}$ to $560 \mathrm{~mW} / \mathrm{cm}^{2}$ ).

Immediately after polymerization, each specimen was individually immersed in $1 \mathrm{ml}$ of $2 \%$ methylene blue solution at $37^{\circ} \mathrm{C} \pm 2^{\circ} \mathrm{C}$. After 24 hours, the specimens were rinsed under running deionized water for 1 minute and stored at $37^{\circ} \mathrm{C} \pm 2{ }^{\circ} \mathrm{C}$ at relative humidity for 24 hours.

To facilitate total dye solubility, the composite resin specimens were removed from the moulds and individually triturated before being immersed in new test tubes containing $1 \mathrm{ml}$ of absolute alcohol for 24 hours.

Standard solutions of methylene blue (Merck, Jacarepaguá, Brazil) in $1 \mathrm{ml}$ of absolute alcohol (Merck, Jacarepaguá, Brazil) were prepared, containing from 0 to $10 \mu \mathrm{g}$ dye $/ \mathrm{ml}$ and a triturated composite resin specimen cured by halogen light, prepared as previously described.

The solutions were filtered and centrifuged for 3 minutes at 4,000 rpm (Dommer CD 100, Dommer Commercial and Industrial Ltd., SP, Brazil). The supernatant was used to determine the absorbance in a spectrophotometer at $590 \mathrm{~nm}$ (Genesys 5, Milton Ray Company, Rochester, NY, USA), as a simple method to evaluate the curing effectiveness of composite resins ${ }^{2,7,17}$. As inadequate composite resin polymerization is directly associated with color instability, spectrophotometric analysis is useful for this evaluation, due to easy dye and pigments diffusion through the resinous matrix ${ }^{7}$, as described by Douglas, Zakariesen $(1981)^{3}$ and modified by Serra et al. ${ }^{19}$ (1994). The effectiveness of composite resin polymerization by light emitting diodes or halogen-based light-curing units was recorded as microgram of dye per milliliter, lower values indicating better equipment.

\section{RESULTS}

For the statistical analysis, the average of the values in micrograms of dye per milliliter of the composite resin polymerized by each light-curing unit was taken. F test was used to evaluate the homogeneity of variance within each group. To verify the differences between groups polymerized by LED or halogen light $t$-test was applied. The statistical analysis was performed using Microsoft Excel (9.0) for Office 2000 Professional (Microsoft, SP, Brazil). No significant differences were found between composite resins light-cured by LED or halogen light-curing units $(p>0.05)$. Table 2 shows the results of the statistical analysis for composite resins photocured by LED or halogenbased light-curing units.

\section{DISCUSSION}

Adequate polymerization depends on light source intensity, light density, wavelength and exposure duration. Unless these parameters are adequate, materials will not polymerize completely and will exhibit poor physical properties that may lead to premature failure. One of the problems that may affect aesthetics of restorations is presence of stains on surface or in bulk of composite resins.

Several photopolymerization systems have been introduced on the market. High intensity curing light - such as plasma arc lamps or argon lasers - presents the advantages of a shorter polymerization time and improved conversion, although higher shrinkage may be expected ${ }^{29}$ due to a higher bond formation. Stresses and strains induced by shrinkage may be detrimental, increasing interfacial gaps and inferior marginal integ- 
Micali B, Basting RT. Effectiveness of composite resin polymerization using light-emitting diodes (LEDs) or halogen-based lightcuring units. Braz Oral Res 2004;18(3):266-70.

rity at the tooth-colored interface. However, reports showed no differences in shrinkage ${ }^{5}$, degree of double bond conversion ${ }^{29}$ and temperature attained by the composite resin ${ }^{5}$ after using laser or halogen-based light-curing unit; reduction in polymerization depth ${ }^{25}$ was also observed.

Soft-start polymerization systems have demonstrated no significant reduction in polymerization shrinkage ${ }^{9,27}$, no differences in hardness ${ }^{9}$ and no better marginal adaptation of composite resin restorations bonded to dentinal cavities ${ }^{18}$.

Apart from these systems, commonly used halogen light-curing units have some specific drawbacks, such as decreasing the light output with time, which may result in a low degree of monomer conversion of composites over time ${ }^{12,15}$ and heat generated by emission of light. Unlike conventional halogen light-curing units, LEDs use semiconductors for blue light generation. A small polymer lens partially collimates the light, with no need for filters and the expected lifetime of several thousand hours without significant degradation of light flux over time ${ }^{8,20}$ is obtained. Thus, LED technologies seem to be promising for overcoming the problems with photo-curing devices.

In this study, no significant differences were found in dye penetration between composite resin polymerized by LED or halogen light. As long as there is sufficient energy at the appropriate wavelength to reach the conversion of double bonds to form the polymer, the source of photons seems not to matter.

A variety of studies was conducted to compare the properties of composite resins polymerized by LED or halogen-based curing devices. Stahl et al. ${ }^{21}$ (2000) showed no differences in physical properties of composite resins polymerized by halogen curing-light and LED. Asmussen, Peutzfeldt ${ }^{1}$ (2003), Mills et al. ${ }^{14}$ (2002), Jandt et al. ${ }^{8}$ (2000), Uhl et al. ${ }^{24}$ (2002) and Hofmann et al. ${ }^{6}$ (2002) also reported similar comparative results when evaluating both polymerization systems, even though these studies used either LED devices with a relatively large number of LEDs and/or concentrating light guide tips. Therefore, several nuances must be addressed in these researches. In the study conducted by Mills et al. ${ }^{13}$ (1999), the irradiance of the halogen light was reduced to coincide with the power density output of the LED unit. Under these conditions, the LED unit did provide a greater polymerization depth than the halogen lamp. Although experimental devices should be developed to enable the understanding of physical and mechanical properties of given materials photopolymerized by these light-curing units and also to obtain more efficient materials, comparisons should be made using the light-curing units operating at their normal intensities $^{10}$, as was done in this study. The same curing time was also used to standardize the experimental design of the study.

When comparing commercially available LED and halogen-based light-curing units, Dunn, Bush ${ }^{4}$ (2002) found low mechanical properties for hybrid and microfill composites cured by blue-emitting diodes. Although LED performs as well as or even better than halogen lights at the same irradiance ${ }^{13}$, commercially available LED units demonstrate markedly lower irradiance values than halogenbased units and may not adequately polymerize resin-based composites, what can lead to restoration failures and adverse pulp responses to nonpolymerized monomers ${ }^{4}$.

Irradiance is an important factor to be pointed out because it represents the number of photons delivered to the sample per unit of time, regardless the area illuminated ${ }^{20}$. Although the irradiance values of the curing units used in this study were different (about $110 \mathrm{~mW} / \mathrm{cm}^{2}$ for LED and $570 \mathrm{~mW} / \mathrm{cm}^{2}$ for the conventional unit), the results show no significant differences in composite resin staining after polymerization by each light-curing unit. This data may be explained due to the LED wavelength of 450 to $480 \mathrm{~nm}$ (information given by the manufacturer) that is ideal for activating materials with camphorquinone as photoinitiator, although halogen light provides greater power density than LED lights ${ }^{11,16}$.

The analysis carried out in this study indicates that a commercially available LED-based curing-light unit is as effective for polymerizing a hybrid composite resin as a halogen-based unit. The many advantages of LED units compared with those of halogen light make future development of these devices promising.

\section{CONCLUSION}

Light-emitting diodes or halogen-based lightcuring units present the same efficiency in curing a hybrid composite resin.

\section{ACKNOWLEDGMENTS}

The authors would like to thank Flávia Martão Flório and Luciane Zanin de Souza for the statistical analysis of this study and Keller Junio da Silva for the spectrophotometric analysis support. 
Micali B, Basting RT. Effectiveness of composite resin polymerization using light-emitting diodes (LEDs) or halogen-based lightcuring units. Braz Oral Res 2004;18(3):266-70.

\section{REFERENCES}

1. Asmussen E, Peutzfeldt A. Light-emitting diode curing: influence on selected properties of resin composites. Quintessence Int 2003;34:71-5.

2. Braga RR, Ferracane JL. Contraction stress related to degree of conversion and reaction kinetics. J Dent Res 2002;81(2):114-8.

3. Douglas WH, Zakariasen KL. Volumetric assessment of apical leakage utilizing a spectrophotometric dye-recovery method [abstract]. J Dent Res 1981;60:438 apud Serra MC, Navarro MF, Freitas SF, Carvalho RM, Cury JA, Retief DH. Glass ionomer cement surface protection. Am J Dent 1994;7(4):203-6.

4. Dunn WJ, Bush AC. A comparison of polymerization by light-emitting diode and halogen-based light-curing units. J Am Dent Assoc 2002;133:335-41.

5. Fano L, Ma WY, Marcoli PA, Pizzi S, Fano V. Polymerization of dental composite resins using plasma light. Biomaterials 2002;23:1011-5.

6. Hofmann N, Hugo B, Klaiber B. Effect of irradiation type (LED or QTH) on photo-activated composite shrinkage strain kinetics, temperature rise, and hardness. Eur J Oral Sci 2002;110:471-9.

7. Imazato S, Tarumi H, Kobayashi K, Hiraguri H, Oda K, Tsuchitani Y. Relationship between the degree of conversion and internal discoloration of light-activated composite. Dent Mater J 1995;14(1):23-30.

8. Jandt KD, Mills RW, Blackwell GB, Ashworth SH. Depth of cure and compressive strength of dental composites cured with blue light emitting diodes (LEDs). Dent Mater 2000;16:41-7.

9. Koran P, Kurschner R. Effect of sequential versus continuous irradiation of a light-cured resin composite on shrinkage, viscosity, adhesion, and degree of polymerization. Am J Dent 1998;11:17-22.

10. Leonard DL. Light-emitting diode curing lights, part I. J Esthet Restor Dent 2003;15:123-6.

11. Leonard DL, Charlton DG, Roberts HW, Cohen ME. Polymerization efficiency of LED curing lights. J Esthet Restor Dent 2002;14:286-95.

12. Martin FE. A survey of the efficiency of visible light curing units. J Dent 1998;26:239-43.

13. Mills RW, Jandt KD, Ashworth SH. Dental composite depth of cure with halogen and blue light emitting diode technology. Br Dent J 1999;186:388-91.

14. Mills RW, Uhl A, Jandt KD. Optical power outputs, spectra and dental composite depths of cure, obtained with blue light emitting diode (LED) and halogen light curing units (LCUs). Br Dent J 2002;193:459-63.
15. Miyazaki M, Hattori T, Ichiishi $\mathrm{Y}$, Kondo M, Onose $\mathrm{H}$, Moore BK. Evaluation of curing units used in private dental offices. Oper Dent 1998;23:50-4.

16. Nomoto R. Effect of light wavelength on polymerization of light-cured resins. Dent Mater J 1997;16:60-73.

17. Rueggeberg FA, Caughman WF, Curtis JW Jr, Davis HC. A predictive model for the polymerization of photoactivated resin composites. Int J Prosthodont 1994;7:15966.

18. Sahafi A, Peutzfeldt A, Asmussen E. Soft-start polymerization and marginal gap formation in vitro. Am $\mathrm{J}$ Dent 2001;14:145-7.

19. Serra MC, Navarro MF, Freitas SF, Carvalho RM, Cury JA, Retief DH. Glass ionomer cement surface protection. Am J Dent 1994;7(4):203-6.

20. Small BW. A review of devices used for photocuring resin-based composites. Gen Dent 2001;49:457-60.

21. Stahl F, Ashworth SH, Jandt KD, Mills RW. Lightemitting diode (LED) polymerization of dental composites: flexural properties and polymerization potential. Biomaterials 2000;21:1379-85.

22. Suh BI. Controlling and understanding the polymerization shrinkage-induced stresses in light-cured composites. Compend Contin Educ Dent 1999;25(Suppl):S3441.

23. Suh BI, Feng L, Wang Y, Cripe C, Cincione F, de Rjik W. The effect of the pulse-delay cure technique on residual strain in composites. Compend Contin Educ Dent 1999;20(2 Suppl):4-12.

24. Uhl A, Mills RW, Vowles RW, Jandt KD. Knoop hardness depth profiles and compressive strength of selected dental composites polymerized with halogen and LED light curing technologies. J Biomed Mater Res 2002;63:72938.

25. Vargas MA, Cobb DS, Schmit JL. Polymerization of composite resins: argon laser $v$ s conventional light. Oper Dent 1998;23:87-93.

26. Weerakoon AT, Meyers IA, Symons AL, Walsh LJ. Pulpal heat changes with newly developed resin photopolymerization systems. Aust Endod J 2002;28:108-11.

27. Yap AU, Ng SC, Siow KS. Soft-start polymerization: influence on effectiveness of cure and post-gel shrinkage. Oper Dent 2001;26:260-6.

28. Yap AU, Soh MS, Siow KS. Post-gel shrinkage with pulse activation and soft-start polymerization. Oper Dent 2002;27:81-7.

29. Yoon TH, Lee YK, Lim BS, Kim CW. Degree of polymerization of resin composites by different light sources. J Oral Rehabil 2002;29:1165-73.
Received for publication on Sep 22, 2003

Sent for alterations on Apr 01, 2004 Accepted for publication on Jun 01, 2004 